\title{
DEVELOPMENT STRATEGIES IN THE FIELD OF LIFELONG LEARNING OF OLDER ADULTS
}

\author{
Hosnjak AM, Ilic B, Kurtovic B, Ledinski Ficko S, SMrekar M. \\ University of Applied Health Sciences, Department of Nursing, Mlinarska cesta 38, \\ 10000 Zagreb, Croatia
}

\begin{abstract}
A b s tract
Introduction: European gerontological research confirms that accelerated aging of the population will lead to a pronounced occurrence of target groups of functionally capable older people. Lifelong learning is a tool that enables an active post-retirement period in order to enhance cognitive mental capacities, prevent dementia, and overcome the intergenerational gap. The aim of this paper is to develop strategies in the field of lifelong learning for older adults through SWOT analysis.

Methods: A qualitative study on lifelong learning for older adults was conducted during the month of November 2019 using 4 SWOT matrices which were subsequently analyzed and integrated into one common matrix. Four strategies were developed based on this template.

Results: The analysis of the SWOT matrix showed that lifelong learning contributes most to a sense of belonging, prevention of social isolation, prevention of dementia, and better personal satisfaction. The biggest obstacles for older people when it comes to participating in lifelong learning programs are finances, physical illness, and a lack of understanding from their family members and the wider society for this kind of activity.

Discussion: Lifelong learning contributes to a long-term maintenance of cognitive processes of participants involved in education processes. Lifelong learning provides the opportunity to promote older people's health regardless of the formal education they received in early adulthood.

Conclusion: Learning and further education are not only the indicators of active aging, but also a need for older people to master new tools so that they can actively participate and contribute to the society.
\end{abstract}

Key words: lifelong learning, strategy, SWOT analysis

\section{INTRODUCTION}

In 2019 there were 703 million people over the age of 65 in the world. The largest portion of the elderly population in the world (260 million) lives in East and Southeast Asia, followed by Europe and North America (over 200 million). In the next three decades the number of elderly people is projected to double, reaching over 1.5 billion by 2050 . All regions will see an increase in the elderly population between 2019 and 2050. The largest increase in the number of older people over the age of 65 is projected to occur in East and Southeast Asia, where it will increase from 261 million in 2019 to 573 million in 2050 (1). Population aging is synchronous with the socioeconomic trends of a particular country.

Improved socioeconomic conditions, medical and technical developments, and improved overall quality of life have led to an increase in life expectancy. Today, education and learning are not just aimed at younger people. The term "lifelong learning" is increasingly used and we are witnessing older people striving to achieve formal, non-formal and informal education.

Some people want to maintain their mental capacity, prevent dementia, or simply keep up with modern times, while others choose to educate themselves at an older age for their own

Corresponding author: Ana Marija Hošnjak; e-mail: anamarija.hosnjak@zvu.hr

(C) 2020 A. M. Hošnjak et al.

This work is licensed under the Creative Commons Attribution-NonCommercial-NoDerivs 4.0 License (https://creativecommons.org/licenses/by-nc-nd/4.0/) 
satisfaction. The fact that older adults have more free time for themselves certainly contributes to this decision to acquire more education.

Non-formal learning refers to activities whereby individuals acquire knowledge, skills, or differences beyond any systematic and organized educational experience provided by an institution. Non-formal learning takes place in everyday contexts, such as interacting with family, friends, and the society, reading books or newspapers, and educating oneself through other interactions with the mass media, such as listening to the radio, watching television, visiting museums and parks, or attending lectures and conferences (2).

It has been almost 17 years since the World Health Organization (WHO) adopted the Active Aging Framework in 2002. It directly influences aging policies and practices around the world and has drawn public attention to the new opportunities and challenges that global aging brings to individuals and societies. Over the last decade there has been an increasing amount of literature on adult education that has identified psychological wellbeing and health as an important part of general benefits of lifelong learning (3).

The Active Aging Framework recognizes that lifelong learning, along with formal education and literacy, is an important factor facilitating participation, health and safety in the aging process. Education prevents decline and reinforces a positive state of stability (4). Given the context of aging in the world, it is important to explore the latest effects of learning, which can be quite invisible but play an important role in maintaining the autonomy, health, and the quality of life of older people (5).

\section{LIFELONG LEARNING}

Many universities, colleges, community centers, and other institutions have created lifelong learning programs and institutes to satisfy the needs and desires of the third age population through valuable activities, intellectual stimulation, and social engagement $(6,7)$.

These programs offer the opportunity to expand one's knowledge on a variety of topics, enhance creativity, and expand and open perspectives (8). Lifelong learning is an integral part of maintaining the competences of older adults. Several studies have examined the orientation towards lifelong learning at different stages of continuing education and careers.

Since the 1960s and 1970s the term lifelong learning has been popularized to express the need for applying educational policies that are not restricted to any age group or education provided by formal institutions. The focus is on learning, not education (9).

Lifelong learning thus involves education conducted using various forms of non-formal education through courses, additional training or retraining, and vocational training.

It is a process of continuous advancement and expansion of knowledge acquired in the formal school system with the aim of improving the existing skills and gaining new knowledge and modern qualifications (10).

Although this offers a potential benefit of further education in older life, only a minority of older adults opts for it. In the United States Hamil-Luker and Uhlenberg (2002) showed that only 16.3 percent of people between the ages of 66 and 75 participated in non-accredited learning activities organized by the community or a business institution, while the National Household Education Survey (NHES) in 2005 estimated that 23 percent of the Americans over 65 years of age participated in a formally organized educational activity in the preceeding year (11).

In Europe Kailis and Pilos (2005) found that 30 percent of people between the ages of 55 and 65 participated in educational activities during the preceding year (11). Also, the rates between the countries are different: in northern Europe 20 percent of those aged 55-74 typically participate in educational activities, while in the Mediterranean countries the rates are below 10 percent (12). 
Today, the Universities of the Third Age are being open worldwide. They operate on the principle of a group and are aimed at people in their third age with the purpose of encouraging them to share their knowledge, skills, and interests in a friendly environment. Such universities are a growing area of research and practice (13).

The latest study on this topic was conducted by Cadorin et al. in 2019 and its aim was to validate a tool for measuring the self-learning ability and to identify learning abilities in older adults attending the University of the Third Age. The authors showed that the participants were highly motivated and responsible for the tasks and learning processes and were able to identify the learning needs and goals. They were also internally motivated to develop the learning method and to organize learning activities. However, the authors also showed that the participants were less able to keep the track of available learning resources (14). Self-directed learning skills are closely linked to lifelong learning and continuous education interventions and enable older people to develop coping and self-preservation strategies (15).

As the population ages and the need to encourage active aging increases $(16,17)$ the ability to learn independently has become crucial among older people and all those who provide care for them.

Another interesting recent study was conducted by Hansen et al. who focused on detecting barriers for older people to enrollment in lifelong learning programs. The authors showed that women were more interested in lifelong learning programs than men. They also showed that there is a difference between races. More specifically, white people are more likely to enroll in these types of programs. Furthermore, older people with lower education exhibit less ambition to join lifelong learning programs (18).

The aim of this paper was to identify the strengths, weaknesses, opportunities, and threats associated with the terminology of lifelong learning in older people using SWOT analysis, and to use the TOWS matrix as a tool for developing strategies in the field of education for older adults.

The purpose of the paper is to demonstrate the benefits of education for older adults using the established framework of strategies and to explore the possibilities of opening a third-age school.

\section{METHODOLOGY}

\section{TYPE OF RESEARCH}

A qualitative study on lifelong learning of older adults was conducted in order to identify the strengths, weaknesses, opportunities, and threats. The resulting data were grouped and linked into a SWOT matrix and then analyzed and integrated into one common matrix that served as the basis for strategy development.

\section{PARTICIPANTS}

In the initial stages of the study, sampling involved the purposeful selection of the sample, i.e. the participants. Four lecturers from the University of Applied Health Sciences in Zagreb participated in the analysis. The lecturers primarily work in the educational process and were willing to participate and produce a SWOT analysis on the topic of lifelong learning. The following criteria were considered when selecting the participants: (1) have sufficient knowledge and experience on the subject, (2) have encountered SWOT analysis before, (3) have sufficient time to produce the matrices.

Two of the participants are senior lecturers, one is a lecturer, and one is an assistant. All of them teach at the Department of Nursing and have, on average, 9 years of work experience 
Table 1 Participant demographics

\begin{tabular}{|l|l|l|l|}
\hline $\begin{array}{l}\text { Lecturer - University of Applied } \\
\text { Health Sciences (L-UAHS) }\end{array}$ & PROFESSION & GENDER & $\begin{array}{l}\text { Years of work experience in } \\
\text { the educational process }\end{array}$ \\
\hline L-UAHS1 & $\begin{array}{l}\text { MSN in Nursing, } \\
\text { PhD candidate } \\
\text { Senior lecturer }\end{array}$ & $\mathrm{F}$ & 13 years \\
\hline L-UAHS2 & $\begin{array}{l}\text { MSN in Nursing, } \\
\text { PhD candidate } \\
\text { Senior lecturer }\end{array}$ & $\mathrm{F}$ & 12 years \\
\hline L-UAHS3 & $\begin{array}{l}\text { MSN in Nursing, } \\
\text { PhD candidate } \\
\text { Assistant }\end{array}$ & $\mathrm{M}$ & 9 years \\
\hline L-UAHS4 & $\begin{array}{l}\text { PhD in Nursing } \\
\text { Lecturer }\end{array}$ & $\mathrm{F}$ & 2 years \\
\hline
\end{tabular}

in the educational process. The demographic data of the interviewed participants are shown in Table 1.

Prior to the SWOT analysis all participants were aware of the goals and purpose of the matrix and that they would serve to develop strategies for the education of older adults. Participation was voluntary. All participants signed an informed consent to participate in the survey. A semi-structured interview on a given topic was personally conducted with each participant. For each area they were also asked questions such as "What do you do well?" (strengths), "What do you consider to be a weakness?" (weaknesses), "What are the opportunities for moving forward regarding the topic in question?" (opportunities), and "What obstacles do you encounter?" (threats). After studying the literature and after clear instructions were provided, 4 SWOT analyses were produced on the topic in question.

\section{QUALITATIVE CONTENT ANALYSIS}

All responses were divided into 4 areas: strengths, weaknesses, opportunities, and threats and four SWOT matrices were created (Attachments A-D). They were originally done by hand using paper and pencil and then digitized at a later stage. If synonyms appeared, the term most commonly used in the Croatian language was considered. Some terms of the same meaning were grouped together so that they would not be repeated in multiple places. The terms with the highest frequency of occurrence are included at the top of the list. The data obtained from four SWOT matrices produced were coded and one comprehensive SWOT matrix was created.

After grouping and discarding the same and/or similar concepts it was shown that when it comes to the topic of lifelong learning in the older population the strengths, of which there are most, 16, far outweigh the other aspects. It was concluded that there were 15 weaknesses, 15 threats and 12 opportunities.

The author of this paper participated in the discussion to improve the analysis, format, and composition of this paper, and by combining all the above mentioned matrices integrated them into one matrix with the developed strategies of SO, WO, ST and WT (Table 2). 


\section{RESULTS}

After analyzing the answers about the strengths, weaknesses, opportunities, and threats of lifelong learning it was shown that all participants had identical or similar impressions, which was expected given the homogeneity of the workplace.

After coding the keywords it was found that all the respondents most frequently cited dementia prevention, i.e. cognitive capacity enhancement, as a strength. Furthermore, they cited prevention of social isolation and self-realization as a strength. The most commonly mentioned weaknesses were foreign language, technology and digitization, as well as illness or disability. The most frequently mentioned opportunity was improvement of social contacts, acquisition of new knowledge, and the possibility for programs to be recognized and funded through EU funds. The most emphasized threats are finances, lack of personal motivation, and physical limitations.

Based on the analysis of strengths, weaknesses, opportunities, and threats four strategies were formulated: SO, WO, ST, and WT, which are presented in Table 2 . The strategies that use the power to maximize lifelong learning opportunities (SO strategies) are most often referred to as opportunities for engaging in various projects and developing a social network, strengthening intergenerational relations and mutual support, which directly affects the following strengths: strengthening cognitive-mental capacities, prevention of dementia, maintaining social contacts, preventing social isolation, and involving people in a more active life. The acquisition of new knowledge and skills is also mentioned as an opportunity to strengthen the forces by which a person acts directly on self-fulfillment, enhancement of personal satisfaction, positive self-perceptions, better psycho-physical feeling, the sense of utility, and the sense of productivity. Mutual support, strengthening intergenerational relations and communication skills, and improving information literacy minimize weaknesses (WO strategy) such as a lack of social and communication skills, slowness, and passivity. Rapid development of medicine, technology, application development, and the possibility of acquiring knowledge, with the support of funding, directly affects the problems of slowness and barriers in the form of foreign languages, which is most commonly mentioned, thus bridging the gap between generations. The sense of personal satisfaction, the sense of utility and productivity, and the sense that something new is being contributed to society is minimized by the threats (ST strategy) of a lack of personal motivation, lack of adjustment, and poor awareness. Poor information about programs and a lack of understanding from the society can be overcome through institutions that provide this type of education, by maintaining social contacts and through forces of cost-effectiveness.

Strategies that minimize weaknesses and avoid threats (WT strategy) are primarily focused on simultaneous monitoring of technological advances and IT literacy by minimizing age discrimination, different levels of education within the group, and overcoming internal resistance and lack of adjustment.

Creating attractive educational programs, establishing interinstitutional connections, and informing the wider community about educational programs for older adults contributes to avoiding a lack of motivation on the part of institutions, as well as a lack of understanding from the society and prejudice about cognitive abilities of older adults. 
Table 2 SWOT analysis and strategies developed in the field of lifelong learning for older adults

\begin{tabular}{|c|c|c|}
\hline & $\begin{array}{l}\text { STRENGHTS } \\
\text { 1. Strengthening the cogni- } \\
\text { tive-mental capacity } \\
\text { 2. Dementia prevention } \\
\text { 3. Maintaining social contacts } \\
\text { 4. Social isolation prevention } \\
\text { 5. Involvement in a more acti- } \\
\text { ve life } \\
\text { 6. Self-fulfillment } \\
\text { 7. Personal satisfaction } \\
\text { 8. Positive self-perception } \\
\text { 9. Better psycho- psychical } \\
\text { feeling } \\
\text { 10. A sense of utility } \\
\text { 11. A sense of productivity } \\
\text { 12. Financial improvement - } \\
\text { cost effectiveness } \\
\text { 13. Specific and additional } \\
\text { newly acquired knowledge } \\
\text { and skills } \\
\text { 14. Sharing previously acquired } \\
\text { knowledge and skills } \\
\text { 15. Promoting values related to } \\
\text { education in old age } \\
\text { 16. The existence of institu- } \\
\text { tions that provide this type } \\
\text { of education }\end{array}$ & $\begin{array}{l}\text { WEAKNESSES } \\
\text { 1. Technology and accelera- } \\
\text { ted digitization } \\
\text { 2. Computer literacy } \\
\text { 3. Foreign languages } \\
\text { 4. Forgetfulness } \\
\text { 5. Lack of social skills } \\
\text { 6. Lack of previous educa- } \\
\text { tion } \\
\text { 7. Tardiness } \\
\text { 8. Physical disability } \\
\text { 9. Chronic diseases and } \\
\text { health status } \\
\text { 10. Lack of interinstitutional } \\
\text { cooperation } \\
\text { 11. Insufficiently attractive } \\
\text { educational programs } \\
\text { 12. Lack of personal motiva- } \\
\text { tion } \\
\text { 13. The trend of passivity } \\
\text { 14. Poor intergenerational } \\
\text { connectivity and infor- } \\
\text { mation sharing } \\
\text { 15. Lack of awareness } \\
\text { among the wider commu- } \\
\text { nity about educational } \\
\text { programs for the elderly }\end{array}$ \\
\hline $\begin{array}{l}\text { OPPORTUNITIES } \\
\text { 1. Engaging in various pro- } \\
\text { jects and developing a } \\
\text { social network } \\
\text { 2. Strengthening intergenera- } \\
\text { tional relations } \\
\text { 3. Mutual support } \\
\text { 4. Strengthening communi- } \\
\text { cation skills } \\
\text { 5. Additional knowledge and } \\
\text { learning of new skills } \\
\text { 6. Rapid development of tech- } \\
\text { nology } \\
\text { 7. Improving IT literacy } \\
\text { 8. Rapid development of } \\
\text { medicine and new devel- } \\
\text { opments } \\
\text { 9. Applications } \\
\text { 10. Public support } \\
\text { 11. Funding opportunities } \\
\text { through EU projects } \\
\text { 12. Recognizing the importan- } \\
\text { ce of lifelong learning by } \\
\text { public and professional } \\
\text { departments }\end{array}$ & $\begin{array}{l}\text { SO STRATEGY } \\
\text { Strategies that use strengths } \\
\text { to maximize opportunities. } \\
\text { 1. Involvement of third-age per- } \\
\text { sons in various projects and } \\
\text { development of a social net- } \\
\text { work (S3, S4, S5, S10, S11, } \\
\text { S14, O1, O2, O3, O4, O5) } \\
\text { 2. Strengthening intergenera- } \\
\text { tional relations and mutual } \\
\text { support } \\
\text { (S3, S4, S5, S7, S8, O2, O3, } \\
\text { O4) } \\
\text { 3. Acquisition of new knowledge } \\
\text { and skills } \\
\text { (S1, S2, S8, S9, S12, S13, } \\
\text { S15, S16, O1, O5, O8, O9, } \\
\text { O12) }\end{array}$ & $\begin{array}{l}\text { WO STRATEGY } \\
\text { Strategies that minimize } \\
\text { weaknesses by taking } \\
\text { advantage of opportunities. } \\
\text { 1. Mutual support for } \\
\text { strengthening intergene- } \\
\text { rational relations and } \\
\text { communication skills } \\
\text { (W3, W10, W11, W12, } \\
\text { W14, W15, O1, O2, O3, } \\
\text { O4) } \\
\text { 2. Improvement of IT literacy } \\
\text { (W1, W2, W3, W6, W11, } \\
\text { W13, O1, O4, O7, O9) }\end{array}$ \\
\hline
\end{tabular}




\section{THREATS}

1. Age discrimination

2. A demanding routine

3. Additional cost

4. Financial deficit

5. Expensive programs

6. Different degrees of education within the same group

7. Insufficient personal motivation

8. Internal resistance

9. Insufficient adjustment

10. Insufficient motivation on the part of institutions that could provide educational programs

11. Poor awareness of lifelong learning programs

12. Prejudice about the cognitive abilities of the elderly

13. Lack of understanding from those around the elderly and lack of support

14. Insufficient connection through public transport

15. Poor mobility

\section{ST STRATEGY}

Strategies that use

strengths to minimize threats.

1. Increasing personal satisfaction, sense of usefulness and productivity

(S2, S5, S6, S7, S8, S9, S10, $\mathrm{S} 11, \mathrm{~T} 1, \mathrm{~T} 7, \mathrm{~T} 8, \mathrm{~T} 9, \mathrm{~T} 12)$

2. Increasing opportunities to contribute to the society (S1, S4, S13, S14, S15, S16, T4, T5, T10, T13, T14)

3. Opportunities to open educational institutions for education of adults (S15, S16, T4, T5, T11, T12, T13, T14, T15)

\section{WT STRATEGY}

Strategies that minimize weaknesses and avoid threats.

1. Simultaneous monitoring of technological advances and IT literacy (W1, W2, W3, W13, T2, T3, T4)

\section{DISCUSSION}

Although they are still qualitatively limited, recent studies examining the link between learning later in life and psychological wellbeing suggest there are long-term benefits for the wellbeing of the participants involved in education processes (19). The study by Jenkins et al. was among the first to examine the association between lifelong learning activities and health using a nationally representative sample of adults aged 50 and above. The results indicate that engaging in lifelong learning provides the opportunity to promote older people's health regardless of the formal education they received in early adulthood. Using a longitudinal study Jenkins et al. examined the long-term effects of different types of lifelong learning on the psychological wellbeing of just over 3,000 older adults $(20,21)$. The authors found that higher levels of education are generally associated with higher levels of wellbeing and that, regardless of the level of education, there is a gradual decline in the psychological wellbeing of older adults if there is no further intervention in later life (21), which correlates with the strategies outlined above. Implications for public health point to lifelong learning as a potential autonomous and sustainable strategy for the reduction of socioeconomic disparities in health, which could be incorporated into education and public health policies to promote such efforts (22). These findings clearly suggest that participation in adult courses functions as a compensatory strategy for adults that helps them develop psychological and social capacities.

Jamieson (23) reports on the results of a qualitative study obtained through interviews with retirees enrolled in courses at a British university. The author was curious about the benefits the retirees had experienced by enrolling in lifelong learning programs. She proved that learning is an integral part of their social lives, which can strengthen or increase their self-esteem, as stated in the benefits of our SWOT analysis. 
Mental stimulation of learning new things was an important advantage and strength for many respondents. Jamieson also states that the respondents considered that the time spent on courses was well-spent. Promoting lifelong learning in older adults can significantly contribute to the wellbeing of the community. The research shows that the more active, healthier and educated older people are, the less they use the resources and services of their family and community.

At the same time, active and healthy older people contribute to the wellbeing of the community through their accumulated life experience, expertise and service, which is also demonstrated by our stated benefits and strategies that maximize opportunities (24).

The results of a 2014 study by Panitsides confirmed the hypothesis that social interaction and professional activities contribute to the creation of a cognitive reserve in the form of a skill set or repertoire, which allows some people to prevent cognitive decline associated with normal aging or neurodegenerative diseases (25).

Considering the aging of the general population, the goal of EU leaders in the future will not only be connected with the problems arising from an aging population, but also finding ways to use their potential.

In relation to the above, the European Parliament (2011) has recognized the fight against dementia using interventions that rely on preventative factors, such as the promotion of physical and cognitive activity, as an urgent priority. In this context, the aim of the proposed project framework is to provide solutions to challenges mentioned above by providing dual level interventions: a) develop and implement educational interventions for cognitive stimulation of older adults (65+) and b) empower older people to act as educators by providing interventions based on cognitive processes (25).

Unfortunately, little research has been conducted so far on how many older people are involved in learning activities, in what type of learning activities they are involved, and what factors predict interest in this type of education. That knowledge is crucial for promoting the participation of older adults in learning activities and for designing activities that could be attractive to older people, as well as satisfy their personal and social needs (9).

The limitation of this qualitative research is in its small sample. However, despite having only four participants, a comprehensive SWOT matrix was created, with the result of four strategies that can be the basis for further development.

\section{CONCLUSION}

In conclusion, those who successfully choose activities related to education and further learning find compensatory strategies optimize desired outcomes and have higher levels of emotional wellbeing and life satisfaction.

Older adults who continue to strive for education after retirement have a sense of continuity and satisfaction that compensates for the changes and consequent anxieties they encounter in daily life.

People over 60 years of age are today striving to acquire better education and informal types of education, health, and financial wellbeing. Learning and further education are not only the indicators of active aging, but also of the need of older people to master new tools so that they can actively participate in and contribute to the society.

Despite the difficulties in including older people into lifelong learning policies, in the last three decades the number of educational programs intended for them has drastically increased.

Funding: This research did not receive any specific grant from funding agencies in the public, commercial, or not-for-profit sectors. 


\section{REFERENCES}

1. United Nations: Department of Economic and Social Affairs, Population Division. World Population Ageing 2019: Highlights. New York. 2019. Available from: https://www.un.org/en/development/desa/population/publications/pdf/ageing/WorldPopulationAgeing2019-Highlights.pdf

2. Ostrouch-Kamińska J, Vieira CC. Private World(s) Gender and Informal Learning of Adults. Research on the education and learning of adults. Rotterdam. 2015 vol 3.

3. Narushima M, Liu J, Diestelkamp N. Lifelong learning in active ageing discourse: its conserving effect on wellbeing, health and vulnerability. Ageing Soc. 2018; 38(4): 651-675.

4. Schuller T, Preston J, Hammond C, Brassett-Grundy A, Bynner J. The Benefit of Learning: The impact of education on Health, Family Life and Social Capital. London. 2004. p.12-33.

5. European commission. Adult learning: It is never too late to learn. Brussels: Commission of the European Communities (COM (2006) 614 final). 2006. Available from: http://eur-lex.europa.eu

6. Pstross M, Talmage CA, Peterson BC, Knopf RC. In search of transformative moments: Blending community building pursuits into lifelong learning experiences. J Educ Culture and Soc. 2017; 8(1):62-78.

7. Talmage CA, Hansen RJ, Knopf RC, Thaxton SP. Directions for 21st Century Lifelong Learning Institutes: Elucidating Questions from Osher Lifelong Learning Institute Studies. Alberta $\mathrm{J}$ of Educ Res. 2018; 64(2):109-125.

8. Talmage CA, Lacher G, Pstross M, Knopf RC, Burkhart KA. Captivating Lifelong Learners in the Third Age: Lessons Learned from a University-Based Institute. Adult Educ Quarterly. 2015; 65(3): 232-249.

9. Villar F, Celdrán M. Learning in later life: participation in formal, non-formal and informal activities in a nationally representative Spanish sample. Eur J Ageing 2013;10(2): 135-144.

10. Perin, V. Cjeloživotno učenje s aspekta poslodavca. Andrag glas 2014;18 (2): 61 -67.

11. Villar F, Serrat R, Celdrán M. Participation of Spanish older people in educational courses: The role of sociodemographic and active ageing factors. J of Euro Soc Policy 2016; 26(5):417-427.

12. Eurostat. Active ageing and solidarity between generations: A statistical portrait of the European Union 2012. Luxemburg 2011. Publications Office of the European Union Available from: https:// ec.europa.eu/eurostat/documents/3217494/5740649/KS-EP-11-001-EN.PDF/1fOb25f8-3c864f40-9376-c737b54c5fcf

13. Talmage CA, Rob M, Slowey M, Knopf RC. Age Friendly Universities and engagement with older adults: Moving from principles to practice. Intern J of Lifelong Educ 2016; 35(5): 537-554.

14. Cadorin L, Grassetti L, Paoletti E, Cara A, Truccolo I, Palese A. Evaluating self-directed learning abilities as a prerequisite of health literacy among older people: Findings from a validation and a cross-sectional study. Int J Older People Nurs 2019; 15(1).

15. Boulton Lewis GM. Education and learning for the elderly: Why, how, what. Educ Geront 2010; 36(3): 213-228.

16. Toronto CE. Health literacy competencies for registered nurses: An e-Delphi Study. J Con Educ in Nurs 2016; 47(12):558-565.

17. LeBlanc RG, Jacelon CS. Self care among older people living with chronic conditions. Inter J Old People Nurs 2018; 13(3).

18. Hansen J, Talmage CA, Thaxton SP, Knopf RC. Barriers to age-friendly universities: lessons from other lifelong learning institute demographics and perceptions. Geront \& Geriat Educ 2019; 1-23.

19. Jenkins A, Mostafa T. The effects of learning on wellbeing for older adults in England. Age \& Soc 2015; 35: 2053-2070.

20. Jenkins A. Participation in learning and wellbeing among older adults. Intern $\mathrm{J}$ of Lifelong Educ 2011; 30(3): 403-420.

21. Jenkins A, Mostafa T. Learning and Wellbeing Trajectories among Older Adults in England. Working Paper. 13-02. Institute of Education, University of London 2013. Available from: at repec.ioe.ac.uk/REPEc/pdf/qsswp1302.pdf

22. Yamashita T, Bardo A, Liu D. Lifelong learning, educational attainment, and health outcomes among older adults in the U.S. Innov in Aging 2018;2(1):468-469. 
23. Jamieson A. Learning in Later Adulthood: Transitions and Engagement in Formal Study. Educ Geront 2012; 38(3):201-211.

24. Merriam SB, Kee Y. Promoting Community Wellbeing: The Case for Lifelong Learning for Older Adults. Adult Educ Quarterly 2014; 64(2):128-144.

25. Panitsides EA. Lifelong Learning as a lever for tackling the ageing phenomenon in the European Union: new challenges, new tools. J of Educ Sci and Psycho 2014; 4(66):01-08.

\section{ATTACHMENTS}

ANNEX A: SWOT ANALYSIS OF LIFELONG LEARNING OF THE ELDERLY (L-UAHS1)

\begin{tabular}{|c|c|}
\hline STRENGHTS & WEAKNESSES \\
\hline $\begin{array}{l}\text { - Psychophysical health } \\
\text { - Financial profit } \\
\text { - Improved self-esteem } \\
\text { - Promoting education-related values } \\
\text { - Transfer of personal knowledge }\end{array}$ & $\begin{array}{l}\text { - Language } \\
\text { - Digitization and modern gadgets } \\
\text { - Lack of IT literacy } \\
\text { - Lack of companionship } \\
\text { - Insufficient previous education } \\
\text { - Insufficient interinstitutional cooperation } \\
\text { - The wider community is insufficiently } \\
\text { informed about these types of education }\end{array}$ \\
\hline OPPORTUNITIES & THREATS \\
\hline $\begin{array}{l}\text { - Rapid development of technology } \\
\text { - Rapid development of medicine } \\
\text { - Application development and the ability to } \\
\text { use such applications } \\
\text { - Recognition of importance of opening such } \\
\text { types of programs }\end{array}$ & $\begin{array}{l}\text { - Failure to adjust } \\
\text { - Resistance } \\
\text { - Those around them do not understand the } \\
\text { need for such programs } \\
\text { - Disability and physical barriers } \\
\text { - Few programs on offer } \\
\text { - Lack of motivation }\end{array}$ \\
\hline
\end{tabular}

ANNEX B: SWOT ANALYSIS OF LIFELONG LEARNING OF THE ELDERLY (L-UAHS2)

\begin{tabular}{|c|c|}
\hline STRENGHTS & WEAKNESSES \\
\hline $\begin{array}{l}\text { - Prevention of dementia } \\
\text { - Self-fulfillment and self-realization } \\
\text { - Positive feeling } \\
\text { - Activity } \\
\text { - New knowledge } \\
\text { - New skills } \\
\text { - Productivity }\end{array}$ & $\begin{array}{l}\text { - Foreign languages } \\
\text { - Technology } \\
\text { - Insufficient previous education } \\
\text { - Non-inclusion and introversion } \\
\text { - Disease } \\
\text { - Disability } \\
\text { - Uninteresting programs } \\
\text { - Lack of motivation }\end{array}$ \\
\hline OPPORTUNITIES & THREATS \\
\hline $\begin{array}{l}\text { - New knowledge } \\
\text { - New skills } \\
\text { - Socializing } \\
\text { - EU funds } \\
\text { - New programs opened }\end{array}$ & $\begin{array}{l}\text { - Age discrimination } \\
\text { - Effort } \\
\text { - Financial burden } \\
\text { - Motivation } \\
\text { - Insufficient advertising of this type of pro- } \\
\text { gram }\end{array}$ \\
\hline
\end{tabular}




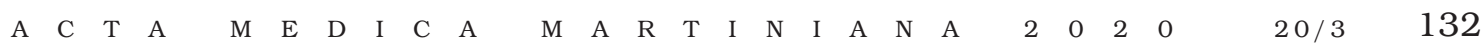

ANNEX C: SWOT ANALYSIS OF LIFELONG LEARNING OF THE ELDERLY (L-UAHS3)

\begin{tabular}{|l|l|}
\hline STRENGHTS & WEAKNESSES \\
\hline $\begin{array}{l}\text { - Dementia prevention } \\
\text { - Strengthening cognitive capacities } \\
\text { - Opening lifelong learning facilities } \\
\text { - New social network }\end{array}$ & $\begin{array}{l}\text { - Modernization of technology } \\
\text { - Slowness } \\
\text { - Dementia } \\
\text { - Illness } \\
\text { - Individual passivity in relation to this type of } \\
\text { program }\end{array}$ \\
\hline OPPORTUNITIES & $\begin{array}{l}\text { THREATS } \\
\text { - EU funds }\end{array}$ \\
$\begin{array}{l}\text { - Strengthening communication skills } \\
\text { Strengthening digital skills }\end{array}$ & $\begin{array}{l}\text { - Minanderstanding of family and society } \\
\text { - Expensive programs } \\
\text { - Disability and mobility }\end{array}$ \\
\hline
\end{tabular}

ANNEX D: SWOT ANALYSIS OF LIFELONG LEARNING OF THE ELDERLY (L-UAHS4)

\begin{tabular}{|l|l|}
\hline STRENGHTS & WEAKNESSES \\
\hline $\begin{array}{l}\text { - Cognitive strengthening } \\
\text { - Prevention of social isolation } \\
\text { - Utility }\end{array}$ & $\begin{array}{l}\text { - Foreign language } \\
\text { - Slowness } \\
\text { - Disability } \\
\text { - Disease }\end{array}$ \\
\hline OPPORTUNITIES & THREATS \\
\hline $\begin{array}{l}\text { - Social contacts } \\
\text { - Spplications }\end{array}$ & $\begin{array}{l}\text { - Financial burden } \\
\text { - Insufficient education } \\
\text { - Lack of motivation } \\
\text { - Poor public transport connections } \\
\text { - Poor mobility }\end{array}$ \\
\hline
\end{tabular}

Received: July, 16, 2020

Accepted: October, 26, 2020 